Article

\title{
Analysis of Water Resources in Horqin Sandy Land Using Multisource Data from 2003 to 2010
}

\author{
Zhenzhen Zhao ${ }^{1}$, Aiwen Lin ${ }^{1, *}$, Jiandi Feng ${ }^{2}$, Qian Yang ${ }^{1}$ and Ling Zou ${ }^{1}$ \\ 1 School of Resource and Environmental Sciences, Wuhan University, Wuhan 430079, China; \\ zzzhao@whu.edu.cn (Z.Z.); yangqianhappy@163.com (Q.Y.); cheryl_zou@whu.edu.cn (L.Z.) \\ 2 School of Geodesy and Geomatrics, Wuhan University, Wuhan 430079, China; jdfeng@whu.edu.cn \\ * Correspondence: awlin@whu.edu.cn; Tel.: +86-27-6877-8926
}

Academic Editor: Marc A. Rosen

Received: 26 January 2016; Accepted: 12 April 2016; Published: 15 April 2016

\begin{abstract}
Over the past four decades, land use/land cover (LU/LC) change, coupled with persistent drought, has resulted in the decline of groundwater levels in Horqin Sandy Land. Accordingly, this study quantifies changes in LU/LC and groundwater storage (GWS). Furthermore, it investigates the effects of LU/LC changes on GWS. GWS changes are estimated using Gravity Recovery and Climate Experiment (GRACE) data and ground-based measurements obtained from July 2003 to December 2010. Soil moisture and snow water equivalent data derived from the Global Land Data Assimilation System (GLDAS) are used to isolate GWS changes from GRACE-derived terrestrial water storage changes. The result shows that the groundwater depletion rate in Horqin Sandy Land is $13.5 \pm 1.9 \mathrm{~mm} \cdot$ year $^{-1}$ in $2003-2010$, which is consistent with the results of monitoring well stations. LU/LC changes are detected using bitemporal imageries (2003 and 2010) from Landsat Thematic Mapper through the post-classification comparison method. The result shows that LU/LC significantly changed during the aforementioned period. Bare soil and built-up land have increased by $76.6 \%$ and $82.2 \%$, respectively, while cropland, vegetation, and water bodies have decreased by $14.1 \%, 74.5 \%$, and $82.6 \%$, respectively. The analysis of GWS and LU/LC changes shows that LU/LC changes and persistent drought are the main factors that affect groundwater resources.
\end{abstract}

Keywords: GRACE; GLDAS; Horqin Sandy Land; groundwater; land use/land cover

\section{Introduction}

Water crisis ranked third among 10 global risks of highest concern in 2015, according to the annual Global Risks Perception Survey of the World Economic Forum. As a crucial source of freshwater worldwide, groundwater is extensively used in drinking water supply, agricultural irrigation, aquaculture, and industrial manufacture [1,2]. Expanding populations and booming economies increase demand for freshwater to supply cities and factories. Groundwater withdrawal continues to increase, particularly in arid and semiarid areas or in highly productive agricultural areas. However, overexploitation or persistent depletion of groundwater occurs if its abstraction exceeds its natural recharge rate over extensive areas for a long period [3,4]. This situation has led to water stress in several parts of the world, including South Africa, central and western U.S., Australia, India, Pakistan, and North China [1,3,5-9]. Groundwater depletion poses a serious threat to the water supply of local residents because it can lead to soil salinization and land subsidence; consequently, it can restrict the social development and economic growth of the affected regions.

Groundwater resources are poorly monitored compared with surface and near-surface water resources $[1,9,10]$. Groundwater resources, which are buried deeply in aquifers, cannot be observed directly; thus, their management is more complex than that of surface water resources [11]. Specialized observation wells or existing wells are conventionally used to monitor groundwater; 
however, this approach is limited by the observation precision of instruments and human errors. Moreover, monitoring systems in some parts of the world are imperfect or not systemically effective. In several cases, records are not released to the public because of a local privacy policy. Thus, although records are available, they may not be reliable or well documented [12].

Launched in 2002, the Gravity Recovery and Climate Experiment (GRACE) provides monthly mass redistribution data [13], which can be used directly to evaluate terrestrial water storage (TWS). Meanwhile, groundwater storage (GWS) changes can be determined by removing snow, ice, surface water, and soil water estimated from hydrology models or other TWS observations $[9,12,14,15]$. Groundwater depletion, even in small (close to or below the GRACE footprint of $\sim 200,000 \mathrm{~km}^{2}$ ) but highly productive agricultural areas where excessive groundwater is abstracted for irrigation, can be detected via updated GRACE processing $[1,10]$.

GWS variations can also be directly estimated using hydrological models (HMs). Wada et al. [16] presented an integrated HM that explicitly simulated groundwater dynamics and pumping in a global land surface model (LSM) that also considered human activities, such as irrigation and reservoir operation. Pokhrel et al. [17] coupled a global water demand model with a global HM and then dynamically simulated daily water withdrawal and consumptive water use from 1979 to 2010.

In addition to GRACE satellite data and HMs, which are used to estimate GWS, multispectral satellite imageries, such as those from Landsat Thematic Mapper (TM), are valuable data sources for the long-term analysis of land use/land cover (LU/LC) changes. Such imageries have powerful capabilities to monitor LU/LC classes (e.g., cropland, vegetation, water, snow, bare soil, and residential) and their evolution in both the spatial and temporal domains. The LU/LC of Horqin Sandy Land has been undergoing dramatic changes along with climate change and the rapidly growing economy and population in the region $[18,19]$. However, previous studies have used only census data at the national and provincial levels. Moreover, a detailed analysis of land transformation remains lacking. Consequently, the effects of LU/LC changes on GWS have been poorly understood. The Landsat TM sensor, which was launched by the National Aeronautics and Space Administration (NASA), was carried onboard Landsat 4 and Landsat 5 from July 1982 to May 2012 with a 16-day repeat cycle. The operational imaging of Landsat 4 and Landsat 5 TM ended in December 1993 and November 2011, respectively. Notably, Landsat 5 TM is currently the longest in-orbit optical remote sensing satellite. Although its minimum life span has been designed for only three years, it has remained in successful in-orbit operation for 27 years. Moreover, Landsat 5 TM is the most widely used and the most significant Earth resource satellite in the world.

This study aims to quantify GWS and LU/LC changes as well as to investigate the effects of LU/LC changes on GWS in Horqin Sandy Land. GWS changes are estimated based on 90 months (July 2003-December 2010) of time-variable gravity field data from GRACE, the Global Land Data Assimilation System (GLDAS), and ground-based measurements. LU/LC changes are detected using bitemporal imageries (2003 and 2010) from Landsat TM through post-classification comparison (PCC).

\section{Study Area}

Horqin Sandy Land $\left(\sim 50,600 \mathrm{~km}^{2}\right)$, which is the largest sandy land in China, is located in the western part of northeastern China between the Inner Mongolian Plateau and the Northeast Plain $\left(119^{\circ} \mathrm{E}\right.$ to $124^{\circ} \mathrm{E}, 42^{\circ} 30^{\prime} \mathrm{N}$ to $\left.45^{\circ} 30^{\prime} \mathrm{N}\right)$ and occupies the eastern part of Inner Mongolia and the western parts of Jilin and Liaoning Provinces (Figure 1) [20]. Horqin Sandy Land, which was once covered with rich grassland vegetation and with forests in some areas [21,22], is now considered an agropastoral transitional zone [23]. This region has also been suffering from severe desertification since the mid-1970s primarily because of long-term overgrazing and estrepement [24]. It belongs to the continental temperate semiarid to subhumid zone with windy and dry winters and comparatively wet summers [25-27]. The Xiliao River Basin, including the drainage of the main streams of the Xiliao River, the Xar Moron River, the Laoha River, and the Jiaolai River [28], occupies the central part of Horqin Sandy Land (Figure 1). Large irrigated farming systems are located around the Xiliao River, 
wherein the main crops are wheat, maize, bean, millet, and sorghum, with patches of rice on the river valleys. Agriculture has become the dominant industry because of the rapid increase in the agricultural population in the past decades [25], which continuously affects the fragile ecosystem. In recent years, developments in the industrial and agricultural sectors have increased the demand for water, severely reduced the amount of surface water, increased groundwater extraction for irrigation, and caused overabstraction of groundwater. These incidents have severely restricted the sustainable use of water resources in Horqin Sandy Land.

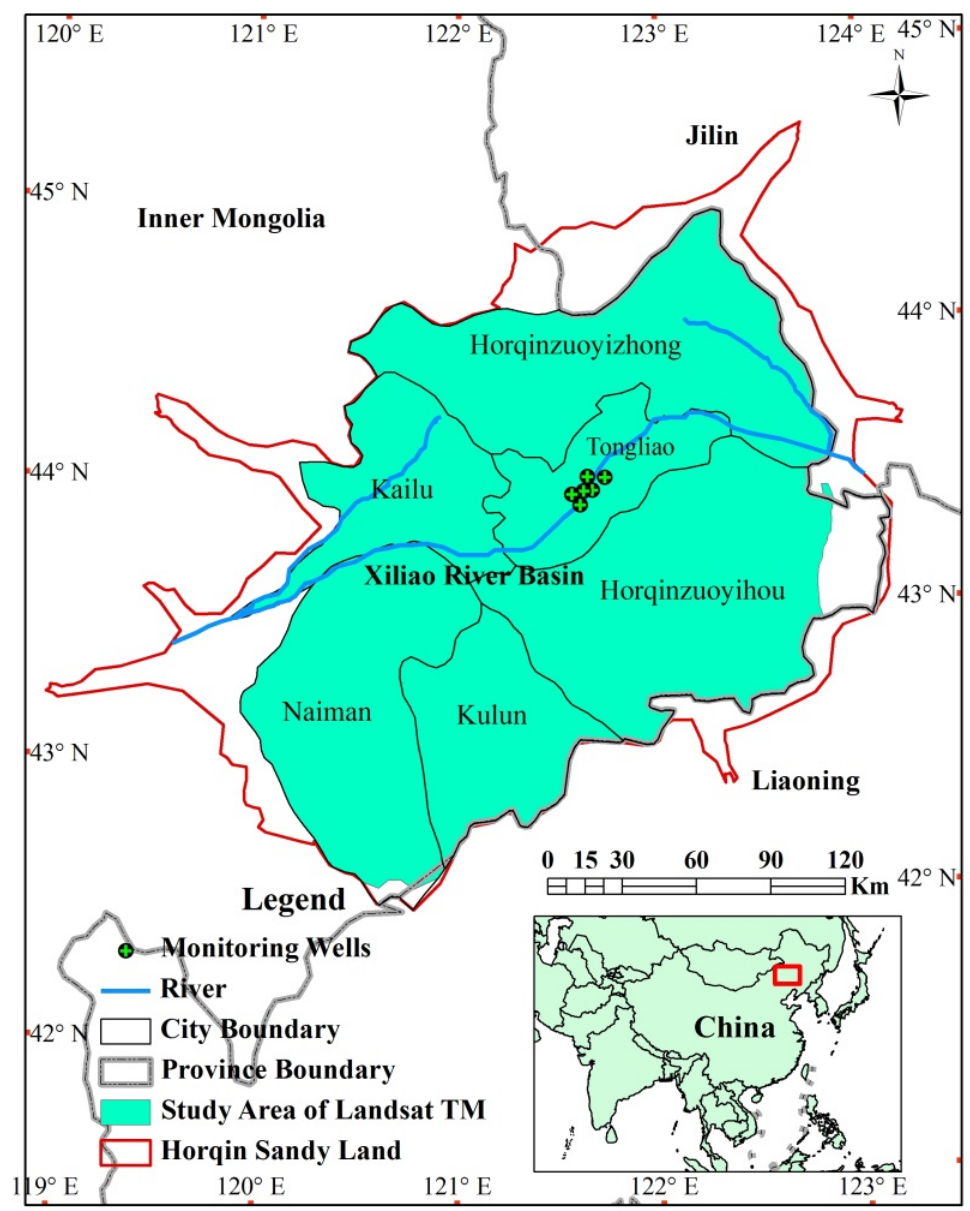

Figure 1. Location of the study area in the northeastern part of China, Inner Mongolia Autonomous Region. The red outline shows Horqin Sandy Land $\left(\sim 50,600 \mathrm{~km}^{2}\right)$ using data from GRACE and monitoring wells to estimate GWS. The green background shows the typical area $\left(\sim 40,558 \mathrm{~km}^{2}\right)$ selected from Horqin Sandy Land using data from Landsat TM imageries to evaluate the effects of LU/LC changes on GWS. The area with the blue background occupies six counties of the prefecture-level city Tongliao. This area is classified by the national government as semipastoral, whereas Horqinzuoyihou and Horqinzuoyizhong are classified as pastoral.

\section{Data and Method}

\subsection{GRACE Data}

Release-05 Level-2 data for 90 months (July 2003-December 2010) provided by the Center for Space Research (CSR) at the University of Texas at Austin are used in this study. Similar to Release-04 data, Release-05 represents total gravity variability, including land surface hydrology, cryospheric changes, episodic (earthquake) processes, glacial isostatic adjustment (GIA), and corrections to background models for atmospheric and oceanic processes. Knowledge on the alignments of the star camera, the 
accelerometer, and the K-band ranging system is also improved for Level-1B data; the mean gravity field, ocean tide, pole tide, and de-aliasing models are updated for Level-2 processing [29].

A filtered solution [30] is adopted for the GRACE data from CSR used in this study to correlate north and south stripes and to reduce the effect of GIA [31]. Meanwhile, a Gaussian filter $(300 \mathrm{~km})$ is used to reduce high-frequency noise. After the mean of the temporal processed solutions is disregarded, the coefficients are converted into $1^{\circ} \times 1^{\circ}$ equivalent water height grids, which are used to extract TWS data in Horqin Sandy Land. The truncation of the gravity coefficients (at a degree and order 60) and the filtered solution may cause signal loss. We restore the power of a lost signal over Horqin Sandy Land by scaling the original estimate of GRACE TWS [32]. Notably, uncertainties exist in this scaling factor approach to restore GRACE signals. Leakage arises from hydrological conditions outside the basin and cannot be generally described by a single multiplicative factor [33]. Moreover, bias and leakage corrections are likely less accurate when reservoir storage is considered a major component of the water balance because GLDAS excludes reservoir storage [34]. On the other hand, scaling factors derived from different LSMs or HMs are similar over most humid, subhumid, and high-latitude regions, but can differ by up to $100 \%$ over arid and semiarid basins as well as areas with intensive irrigation [35]. Long et al. [36] found that filtered GRACE TWS changes applied with PCR-GLOBWB scaling factors exhibit closer agreement with water budget estimates of TWS changes than those applied with scaling factors from other LSMs in the Yangtze River Basin.

Horqin Sandy Land belongs to the continental temperate semiarid to subhumid zone with windy and dry winters and comparatively wet summers [25-27]. The scaling factor for this region may vary when different LSMs or HMs are used. We compare the scaling factors for this region calculated by Landerer and Swenson [37], Long et al. [35], and Long et al. [36], respectively, and found that the factor scaling for Horqin Sandy Land derived from different HMs is also different, but the gap is relatively small. In this case, we just followed Landerer's work, in which the scaling factor is derived by least square fit between spatially averaged filtered and unfiltered modeled TWS anomaly (TWSA) time series from GLDAS-NOAH [37]. The scaling factor for Horqin Sandy Land is 0.7, which is derived from the scaling factor data set calculated by Landerer and Swenson [37]. This value indicates that the original GRACE signal is amplified in Horqin Sandy Land using a low-pass filtering process. Moreover, the estimation method for the basin-specific time-invariant error [38] is adopted to approximate satellite measurement and leakage errors from out-of basin signals.

\subsection{Groundwater Level Data}

In this study, groundwater-level data observed from six monitoring wells located at the center of Horqin Sandy Land (shown in Figure 1) are used as comparative information. The records of the six monitoring wells are obtained from the China Geological Environmental Monitoring the Groundwater Level Yearbook. This yearbook has been published annually by the China Geological Environmental Monitoring Institute since 2005. Accordingly, the span of the monitoring well records used in this study is only from 2005 to 2010. Monitoring well data are observed every 10 days. As the comparative information for GRACE results, the sample interval of observations is converted from 10 days to a month. The mean of the monthly well-level data is disregarded to compute well-level change, which is then converted into GWS change by multiplying the specific yield of the monitoring wells [30]. In $\mathrm{Yu}$ [39], the prefecture-level city of Tongliao, which occupies the majority of Horqin Sandy Land, is divided into 562 triangular spaces. The specific yields of each space are also estimated using the Kriging algorithm based on several known specific yields of unconfined aquifer and laboratory test data, with a mean square error (MSE) $<0.001$ [39]. Following this previous work, the specific yields of the monitoring wells in Horqin Sandy Land is regarded as 0.09-0.1.

Quaternary Holocene alluvium is the main geological feature in Horqin Sandy Land [40]. Groundwater aquifers have two types, namely, phreatic and confined aquifers. Apart from the confined aquifer composed of Quaternary unconsolidated rocks existing in the northeast region of the Horqin left middle banner, the pore-space water in loose rocks of other vast areas belongs to 
phreatic aquifers [41]. In this study, the monitoring wells are distributed at the center of the western Liaohe Plain, wherein the groundwater hydraulic type is phreatic aquifer. The buried depths of the underground water level monitored by the six wells used in this study differ for various wells, with the maximum, minimum, and average values of $15,6.5$, and $10.5 \mathrm{~m}$, respectively. We use the average value of the data from these six wells to study groundwater change trend in this region. The data source is limited, i.e., the China Geological Environmental Monitoring the Groundwater Level Yearbook records only observational data from the six national monitoring stations under normal operation. These stations are located within a small area at the center of Horqin Sandy Land. Nonetheless, as described in the Section 4.1, the GWS anomaly (GWSA) obtained from these wells is in good agreement with the variable law of groundwater estimated by Moiwo [42] and Wei [43]. Therefore, we believe that these wells can basically reflect the general groundwater change trend in the region.

\subsection{Hydrological Models}

Total TWS variability in many regions can be approximated as the sum of snow, soil moisture, and groundwater changes [1,9]. GLDAS, which is jointly developed by the Goddard Space Flight Center of NASA and the National Centers for Environmental Prediction (NCEP) of the National Oceanic and Atmospheric Administration (NOAA), uses both ground- and space-based observations to constrain modeled land surface states [44]. This system can also provide high-resolution products, including soil moisture and snow water equivalent data. Different LSMs of GLDAS can generally provide consistent timing of SMS changes, but may derive considerable differences in SMS magnitude under extremely dry and extremely wet conditions [45], which is most likely caused by the different evapotranspiration parameterization schemes of different LSMs $[45,46]$. In this study, soil moisture (1.0 degree/monthly data) is estimated by averaging the results from five simulations of the GLDAS system [44], which span from July 2003 to December 2010. Three meteorological forcing data sets and three LSMs are adopted for these five simulations using statistical assimilation techniques [47]. Soil moisture calculated using GLDAS integrates the influence of solar radiation, ambient temperature, precipitation, and other meteorological factors [44]. Uncertainties in the GLDAS-modeled SMS changes are estimated from the standard deviation of SMS changes from the five contributing simulations, which is $1.6 \mathrm{~mm} \cdot$ year $^{-1}$ The snow water equivalent trend computed from GLDAS data is less than $0.001 \mathrm{~mm} \cdot$ year $^{-1}$, which can be disregarded in this study area. Thus, GWS is estimated by removing GLDAS-modeled soil moisture from GRACE-derived TWS. Notably, regional water storage changes caused by human activities, such as irrigation and dam construction, are not considered in the GLDAS system.

We estimate the validity of the GRACE-derived TWS using the independent TWS source calculated with the Climate Prediction Center (CPC) model from NCEP of NOAA. GRACE data can capture all the changes in mass, including changes that cannot be estimated using the CPC HM; consequently, differences may exist between the TWS derived by GRACE and that derived by CPC. However, if GRACE correctly calculates TWS, then the variation trend of the GRACE-derived TWS should be consistent with that of the CPC-derived TWS. This model uses global precipitation observations, geographic distribution of solar radiation, surface pressure, humidity, temperature, and horizontal wind velocities to provide snow distribution and soil moisture products. From January 1948 until the present, the temporal and spatial resolutions of the model are one month and $0.5^{\circ} \times 0.5^{\circ}$, respectively. In the current study, TWS changes from July 2003 to December 2010 are simulated using the CPC model.

\subsection{Landsat TM and Preprocessing}

Bitemporal imageries (2003 and 2010) from Landsat TM provided by the Geospatial Data Cloud (GSCloud) are used in this study to evaluate the effects of LU/LC changes on GWS (Figure 2). Landsat TM imageries consist of seven spectral bands (blue, $0.45-0.52 \mu \mathrm{m}$; green, $0.52-0.60 \mu \mathrm{m}$;

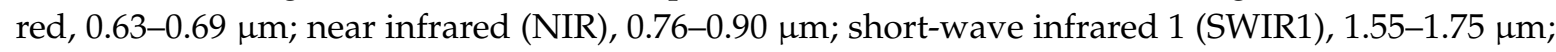
thermal infrared, 10.40-12.50 $\mu \mathrm{m}$; and SWIR2, 2.08-2.35 $\mu \mathrm{m}$ ), with a spatial resolution of $30 \mathrm{~m}$. The approximate scene size is $170 \mathrm{~km}$ north-south $\times 183 \mathrm{~km}$ east-west. This study selects four scenes 
for each period of the study area from the satellite imageries based on the Worldwide Reference System-2. The paths and rows (path/row) of the selected scenes are 120/29, 120/30,121/29, and $121 / 30$, which provide cloud-free pixels and a scenario from July to September. Although the TM imagery provided by GSCloud is processed through the Level-1 Product Generation System, it does not have the physical magnitude of encoded information nor is it free from atmospheric effects. In these cases, the preprocessing method that consists of radiometric calibration and atmospheric correction is applied. Radiometric calibration, which is the first integrant stage, transforms the calibrated digital number into absolute units of spectral radiance [48]. In response to the high demand for an LU/LC classification and change detection (CD) method, an atmospheric correction algorithm is applied to correct ozone, water vapor, and aerosol effects on TM imageries [49]. The current study uses the model developed by Spectral Sciences, Inc., namely, Fast Line-of-sight Atmospheric Analysis of Spectral Hypercubes, to correct visible wavelengths in NIR and SWIR. After the aforementioned preprocessing, TM imagery is corrected through normalization and accurate surface reflectance.

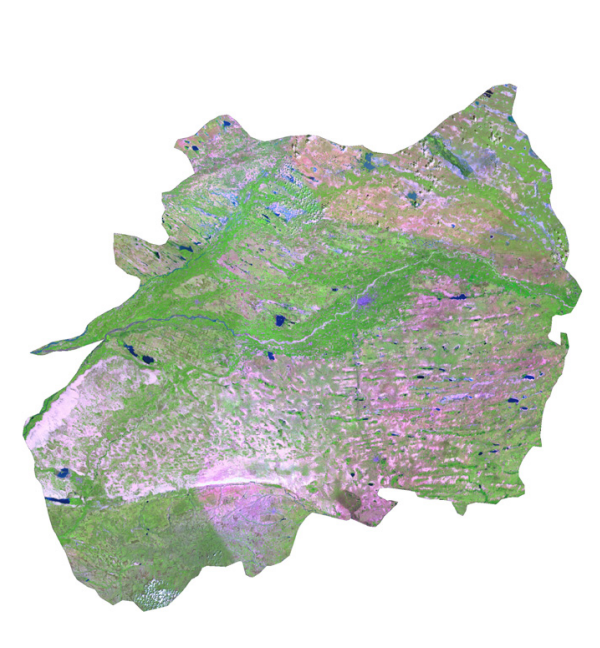

(a)

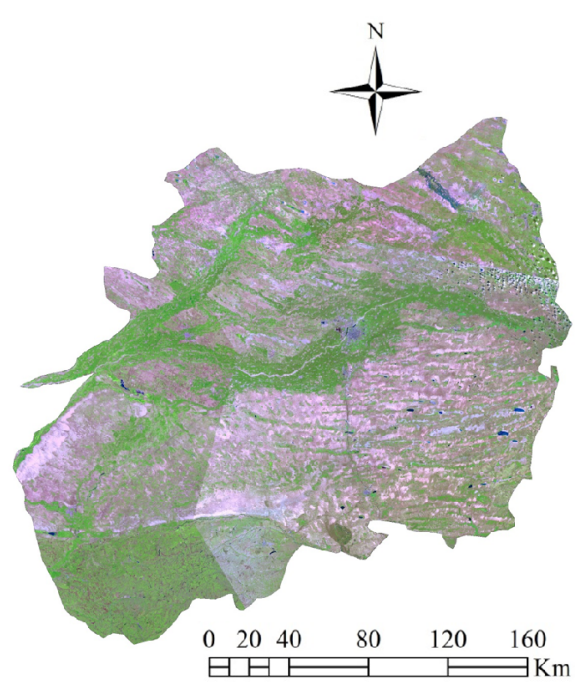

(b)

Figure 2. Bitemporal imageries from Landsat TM: (a) the imagery ( $R G B=$ bands $5,4,3)$ spliced from four scenes in 2003, 120/29 on 3 July, 120/30 on 10 August, and 121/29 and 121/30 on 13 September; and (b) the imagery (RGB = bands 5,4,3) spliced from four scenes in 2010, 120/29 on 15 July, 120/30 on 17 September, and 121/29 and 121/30 on 10 August.

\subsection{LU/LC Change Detection}

Widespread changes in LU/LC in Horqin Sandy Land have occurred as a result of the expansion of sandy and residential areas as well as the reduction of surface water and rangeland areas. LU/LC changes exert considerable influence on hydrological processes, particularly on GWS [50]. Understanding LU/LC changes and their effects on GWS is necessary to optimize the management of natural resources and to protect groundwater resources, in terms of both quantity and quality. This study uses Landsat TM imageries to detect LU/LC changes in Horqin Sandy Land.

An efficient $C D$ research should generally provide the following information: (a) the spatial distribution of the changed area; and (b) the types of changes. When conducting a CD project, the main step is to select suitable techniques. Selecting the appropriate method for a specified CD project is closely associated with determining change direction, multisource data, and research region features. The results derived from remote sensing images can be divided into two directions: (a) change/no change (e.g., image differencing, vegetation index, and tasseled cap transformation (K-T)); and (b) "from-to" change (e.g., PCC and change vector analysis) [51]. On the basis of the preceding CD directions, considerable efforts have been exerted by researchers to develop different $\mathrm{CD}$ methods, 
which can be generally divided into two broad categories: pixel-based [52] and object-based (OBCD) methods [53]. Pixel-based CD techniques are suitable for images with medium or low spatial resolution (e.g., MODIS, Landsat satellites, SPOT, and radar) [54,55]. By contrast, OBCD methods are considered appropriate for images with high or very high spatial resolution (e.g., GeoEye, WorldView-I/II, QuickBird, IKONOS, and OrbView) [56,57]. The characteristics of the study area should also be considered when selecting a CD method [58-60]. A large area that uses low- and medium-resolution data frequently utilizes pixel-based techniques, whereas local scale studies that use very high-resolution data adopt object-based techniques.

The objective of the current study is to obtain "from-to" changes using medium spatial resolution TM images to analyze the effects of these changes on GWS. Hence, the PCC method based on pixels is developed in this study. This method consists of two main steps: (a) classification using a maximum likelihood classifier; and (b) comparison with bitemporal classification maps. The developed method can provide complete change matrices that clearly present "from-to" information. According to the characteristics of the designated area and data, LU/LC is grouped into five classes: (1) cropland; (2) water bodies; (3) built-up land; (4) vegetation; and (5) bare soil. The definition for each class is presented in Table 1.

Table 1. Description of land use/land cover (LU/LC) classes.

\begin{tabular}{cl}
\hline LU/LC Class & \multicolumn{1}{c}{ Description } \\
\hline Cropland & Land cultivated for crops, including paddy land and dry land \\
\hline Water bodies & $\begin{array}{l}\text { Bodies of water, including natural bodies of water (e.g., streams, rivers, } \\
\text { and lakes) and artificial structures (e.g., reservoirs and ponds) }\end{array}$ \\
\hline Built-up land & $\begin{array}{l}\text { Lands used for urban built-up areas, rural settlements, factories, roads, } \\
\text { and other artificial structures }\end{array}$ \\
\hline Vegetation & $\begin{array}{l}\text { Woodland (e.g., forests, shrubs, and gardens) and grassland (e.g., shrub } \\
\text { rangeland and mixed rangeland) }\end{array}$ \\
\hline Bare soil & $\begin{array}{l}\text { Sand dunes, salinized soil, bare ground, and exposed soil with less than } \\
5 \% \text { vegetation cover }\end{array}$ \\
\hline
\end{tabular}

\section{Results and Discussion}

\subsection{GWS Changes}

Figure 3a shows the time series of a TWSA in Horqin Sandy Land estimated using GRACE data and CPC, both of which show TWS loss in the area. The rate of GRACE-derived TWS depletion from July 2003 to December 2010 is $-13.2 \pm 2.6 \mathrm{~mm} \cdot$ year $^{-1}$ equivalent water height, whereas the rate of overall storage depletion in the same area (western JiLin) from January 2002 to December 2009 estimated by Moiwo [42] in 2012 is $-10.2 \mathrm{~mm} \cdot$ year $^{-1}$ ( $\left.-0.85 \mathrm{~mm} / \mathrm{month}\right)$. The rate of TWS depletion in Horqin Sandy Land described in a TWS map of China and the surrounding regions from 2003 to 2010 [9] is approximately $-12 \mathrm{~mm} \cdot$ year $^{-1}$. The results of both of these previous works agree well with the result of the present work, which demonstrates the validity of the GRACE processing used in this work. The time series of the GRACE-derived TWS and that of the CPC-derived TWS also exhibit good agreement, particularly in the phases, and their correlation coefficient is 0.72 . However, the time series of the two TWS data have a minor difference, namely, the amplitude of the GRACE-derived TWS is slightly higher than that of the CPC-derived TWS. The main reason for such difference is that GRACE data can capture all the changes in mass, including changes that cannot be estimated using the CPC HM [61]. 


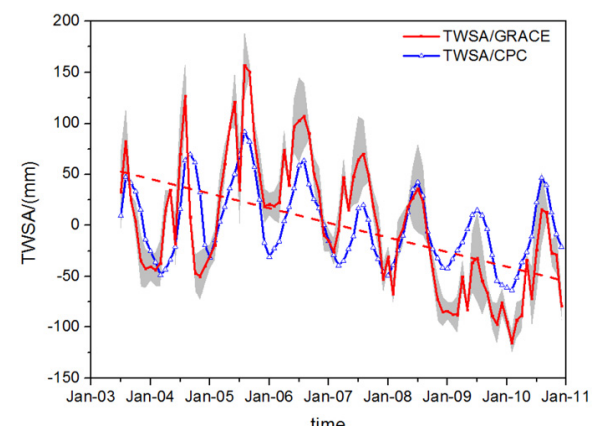

(a)

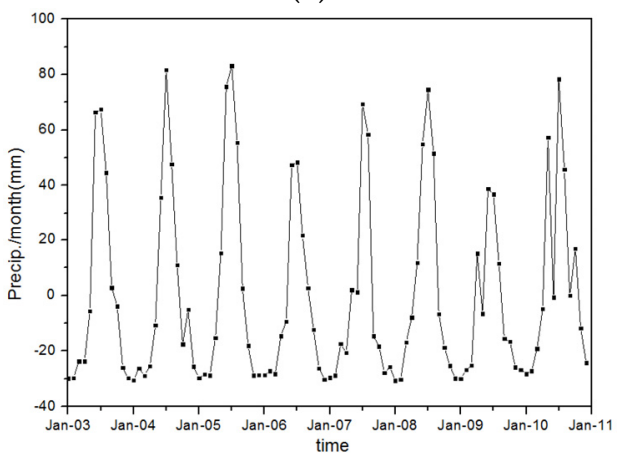

(c)

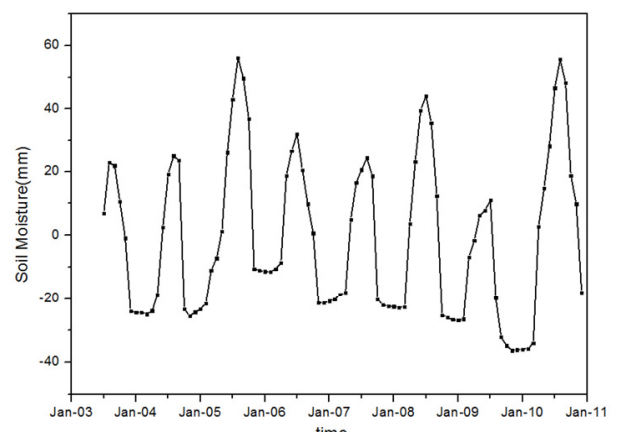

(b)

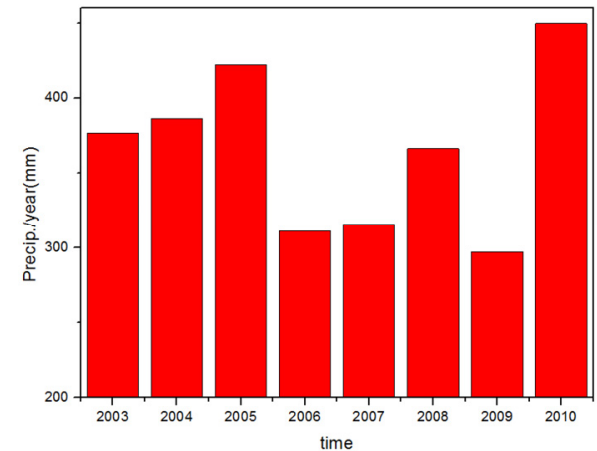

(d)

Figure 3. TWSA, soil moisture and precipitation in Horqin Sandy Land from 2003 to 2010. (a) Monthly TWSA estimated from the GRACE data and the CPC model (the gray shading shows TWSA/GRACE errors); (b) monthly soil moisture simulated from the Global Land Data Assimilation System (GLDAS); (c) monthly precipitation from the China Meteorological Data Sharing Service System; and (d) annual precipitation from the China Meteorological Data Sharing Service System.

Horqin Sandy Land has a wet summer, with most of the precipitation occurring from June to August and seldom in winter and spring (Figure 3c). Both TWS and soil moisture changes (Figure 3b) considerably depend on precipitation (Figure $3 c, d$ ), which indicates a significant seasonal variation. Figure $3 \mathrm{~d}$ shows that annual precipitation dramatically changes, with the minimum (below $300 \mathrm{~mm}$ ) occurring in 2009 and the maximum (over $450 \mathrm{~mm}$ ) occurring in 2010, and demonstrates an overall declining trend from 2005 to 2009. A severe drought has occurred in northern China in 2009 [62], which is presented in Figure 3a-d. GRACE-derived TWS, soil moisture, and precipitation data exhibited a dramatic decline in 2009. The increase in precipitation in 2010 resulted in the growth trend of both TWS and soil moisture.

Figure 4 shows the monthly GWSA estimated by removing soil moisture from GRACE-derived TWS as well as from the trends of GWS at different periods in Horqin Sandy Land. The time series of GWSA from July 2003 to December 2010 showed that GWS was reduced at a rate of $13.5 \pm 1.9 \mathrm{~mm} \cdot$ year $^{-1}$. However, GWS did not maintain a decreasing trend. It increased at a rate of $30.2 \pm 4.1 \mathrm{~mm} \cdot$ year $^{-1}$ during the beginning of the time series from July 2003 to July 2005 . Then, it decreased sharply at a rate of $26.7 \pm 2.7 \mathrm{~mm} \cdot$ year $^{-1}$ from January 2005 to December 2009. Finally, GWS depletion slowed down at the rate of only $6.0 \pm 1.9 \mathrm{~mm} \cdot$ year $^{-1}$ during the last few months of the time series from July 2009 to December 2010.

Figure 5a shows the monthly GWSA observed through the monitoring wells from January 2005 to December 2010, which also presents a continuously decreasing tendency. The change in groundwater level from January 2005 to December 2010 was approximately $1 \mathrm{~m}$, which exhibited good agreement with the results of Moiwo [42] and Wei [43]. 


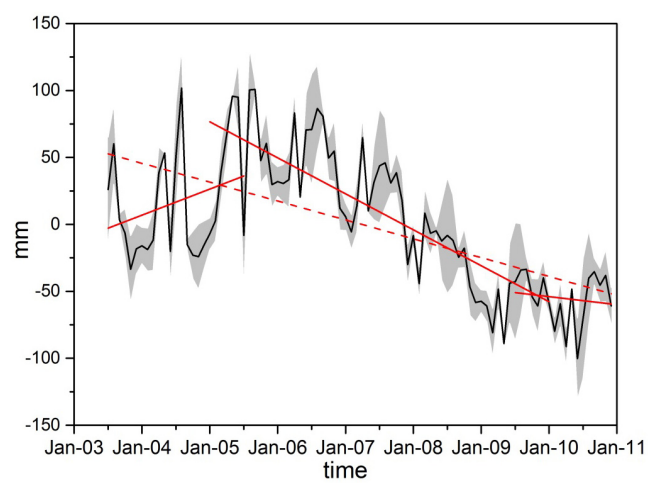

Figure 4. Monthly GWSA estimated by removing soil moisture from the GRACE-derived TWS. The gray shading shows monthly errors. The dotted line describes the overall trend of GWS from July 2003 to December 2010 in Horqin Sandy Land. The three red straight lines describe the trend of GWS in three periods (July 2003 to July 2005, January 2005 to December 2009, and July 2009 to December 2010).

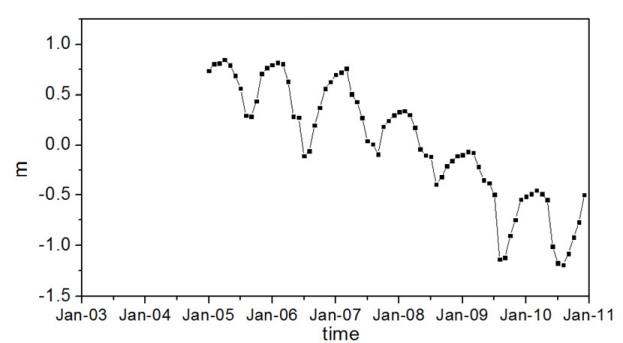

(a)

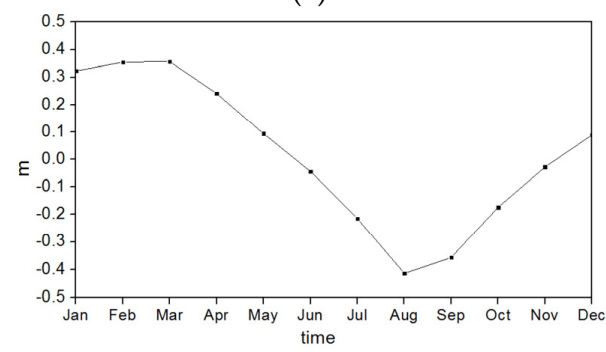

(b)

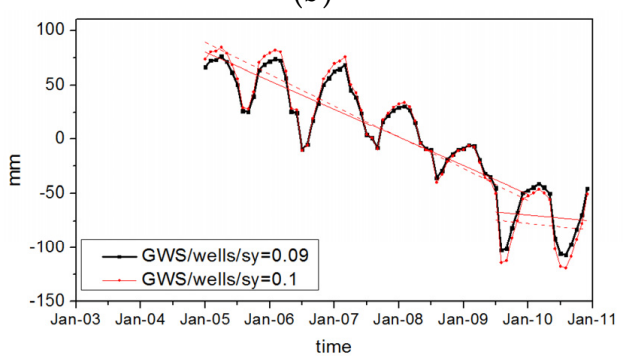

(c)

Figure 5. Groundwater changes derived from monitoring wells. (a) Monthly GWSA from January 2005 to December 2010 in Horqin Sandy Land; (b) average monthly GWSA from January 2005 to December 2010 in Horqin Sandy Land; and (c) monthly GWSA estimated by multiplying GWSA and average specific yield. Monthly GWSAs with specific yields of 0.09 and 0.1 are plotted in black and red lines, respectively, and their trends are plotted in dotted and solid lines, respectively.

We calculate the average monthly GWSA to analyze the seasonal variation of groundwater level (Figure 5b). The peak of the groundwater level is opposite to the seasonal variation in precipitation (Figure 3c); therefore, this peak appears in March, whereas the minimum value appears in August 
(Figure $5 b$ ). This finding is most likely caused by the seasonal extraction of groundwater for irrigation [63-65]. Figure 5c shows the monthly GWSA estimated by multiplying GWSA with the average specific yield. The well-derived GWS data have two periods. In the January 2005-December 2009 period, GWS declined at a rate of $26.04-29.1 \mathrm{~mm} \cdot$ year $^{-1}$ equivalent water height, whereas in the July 2009-December 2010 period, depletion slowed down at a rate of $5.5-6.1 \mathrm{~mm} \cdot$ year $^{-1}$. Groundwater level data are available for only six years (2005 to 2010); thus, we simply compare the data from 2005 to 2010, which are summarized in Table 2. Table 2 indicates that the GRACE-derived GWS data present good agreement with the well-derived GWS data.

Table 2. Water storage trends in Horqin Sandy Land.

\begin{tabular}{ccc}
\hline Time & GWS & Trend (mm· year ${ }^{-\mathbf{1}}$ ) \\
\hline \multirow{2}{*}{ January 2005-December 2009 } & GRACE-derived GWS & -26.04 to 29.1 \\
& well-derived GWS & $-26.7 \pm 2.7$ \\
\hline \multirow{2}{*}{ July 2009-December 2010 } & GRACE-derived GWS & $-6.0 \pm 1.9$ \\
& well-derived GWS & -5.5 to 6.1 \\
\hline
\end{tabular}

In conclusion, both GRACE and the monitoring wells show that GWS present an overall decreasing trend from 2003 to 2010.

\subsection{LU/LC Change Detecton}

Figure 6a,b show the classified images of Horqin Sandy Land from 2003 and 2010, respectively. The classification process is completed after minimal but necessary manual editing. Horqin Sandy Land is the largest sandy land in China. Land use in this area is dominated by croplands, bare soil, and vegetation with minor areas of built-up lands and water bodies (Figure 6a,b). Croplands and built-up lands are mainly distributed along the Xiliao River Basin, whereas a few are distributed in sandy regions. The water bodies in this study area mainly include rivers, particularly the Xiliao River Basin, and some small lakes and ponds. The primary bare soil zone develops in the southern and northern parts of the study area. Vegetation areas appear mainly along croplands and bare soil lands.

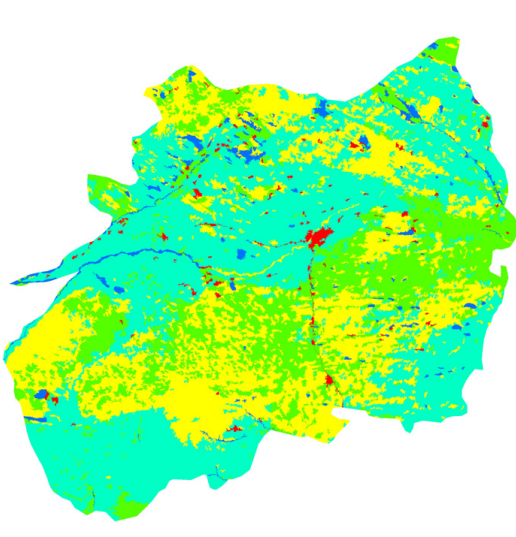

(a)

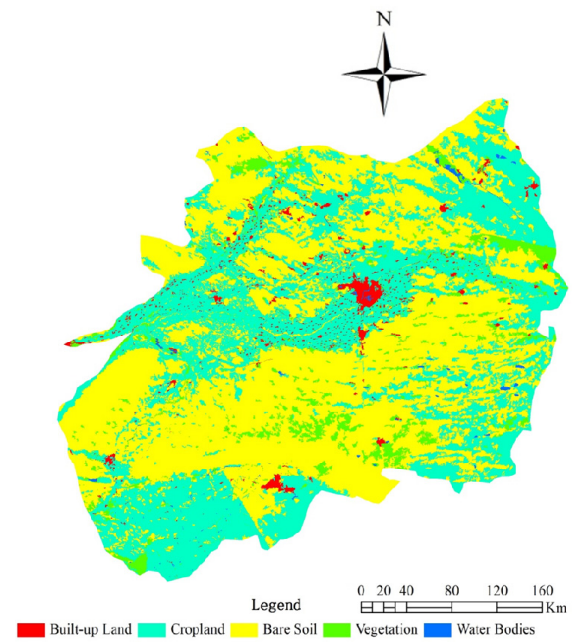

(b)

Figure 6. Land use/land cover (LU/LC) classification in (a) 2003 and (b) 2010 in Horqin Sandy Land.

Bare soil increased by $9421.2 \mathrm{~km}^{2}$ from $12,356.4 \mathrm{~km}^{2}$ in 2003 to $21,777.6 \mathrm{~km}^{2}$ in 2010 , and the increase rate reached $76.2 \%$. Meanwhile, built-up land increased by $366.2 \mathrm{~km}^{2}$ in the seven-year period from $411.7 \mathrm{~km}^{2}$ to $777.9 \mathrm{~km}^{2}$ at a rate of $88.9 \%$. Simultaneously, cropland, vegetation, and water bodies 
decreased rapidly. Cropland decreased by $2585.1 \mathrm{~km}^{2}$ in the seven-year period from $18,211.1 \mathrm{~km}^{2}$ to $15,626.0 \mathrm{~km}^{2}$ at a rate of $14.2 \%$. Vegetation was nearly $8713.7 \mathrm{~km}^{2}$ in 2003 , but was reduced to $2225.4 \mathrm{~km}^{2}$ in 2010 at a high rate of $74.5 \%$. Water bodies decreased by $714.0 \mathrm{~km}^{2}$ from $866.4 \mathrm{~km}^{2}$ in 2003 to $152.4 \mathrm{~km}^{2}$ in 2010 at the sharp decrease rate of $82.4 \%$. In conclusion, five major trends are evident in LU/LC changes (Figures 6 and 7). Built-up land and water bodies demonstrated the greatest changes (over $82 \%$ ). Cropland decreased by $2585.1 \mathrm{~km}^{2}$. The radices of croplands remained extremely large; consequently, its change rate was relatively small (only $14.2 \%$ ). Vegetation area decreased sharply, whereas a marked increase was observed in bare soil areas.

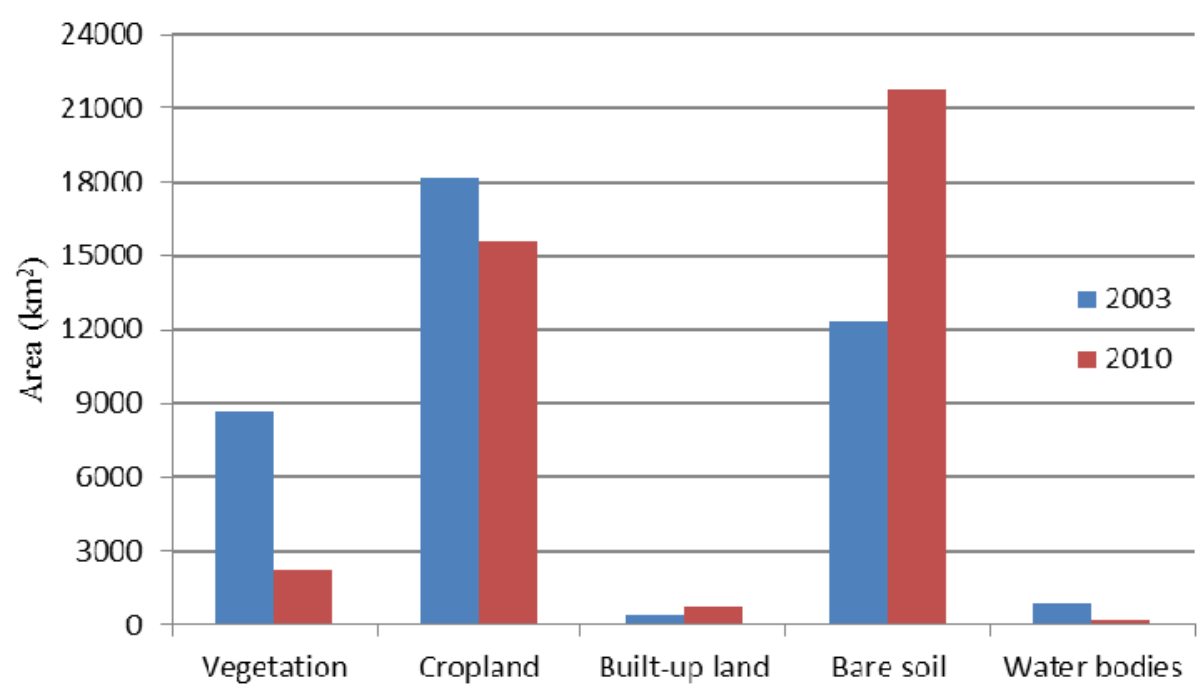

Figure 7. LU/LC change trend over the period from 2003 (blue) to 2010 (red) in Horqin Sandy Land.

The areas of bare soil and built-up land nearly doubled over the seven-year period, increasing from $30.5 \%$ and $1 \%$ of the study area, respectively, in 2003 to $53.7 \%$ and $1.9 \%$, respectively, in 2010 . By contrast, the area of water bodies declined by more than fivefold, decreasing from $2.1 \%$ of the study area in 2003 to $0.4 \%$ in 2010 , whereas the area of vegetation decreased nearly fourfold from $21.5 \%$ in 2003 to $5.5 \%$ in 2010. Croplands decreased in large acreage from $44.9 \%$ to $38.5 \%$ over the seven-year period. Vegetation and cropland clearly transformed into bare soil in large acreage between 2003 and 2010 in Horqin Sandy Land.

We perform two independent assessments for the years 2003 and 2010. Overall, the quality of the obtained classification is satisfactory, i.e., the overall accuracy levels for the two years are $89.2 \%$ and $91.5 \%$, respectively. Therefore, we are confident about these $C D$ products.

The PCC CD method is performed using the classification images from 2003 and 2010 to obtain the detailed information of LU/LC conversion. The result is presented in Figure 8. During this period, croplands exhibited contraction mainly in the northern and southeast bare soil regions. The main reasons for cropland contraction were government initiatives and natural factors. The central government implemented several measures to prevent sandstorms and to protect ecological integrity. Through these measures, the families of local peasants and shepherds were moved from desert steppes and fragile ecotopes, and settled in new villages, which were mainly located along the Xiliao River Basin. Despite these measures, the environmental deterioration of Horqin Sandy Land continues, and croplands are being rapidly overtaken by sand. Over the period of 2003-2010, natural and human factors led to a decrease in the total area of croplands and an increase in the total area of bare soil. The average annual precipitation in Horqin Sandy Land is $300-500 \mathrm{~mm}$, which is the critical level for rain-fed agriculture; hence, the importance of climate variability and trends is evident [25]. To obtain stable grain output and economic income, local famers tend to pump groundwater to prevent cropland drought. Therefore, although the total cropland area has decreased, the irrigated cropland area has increased. 

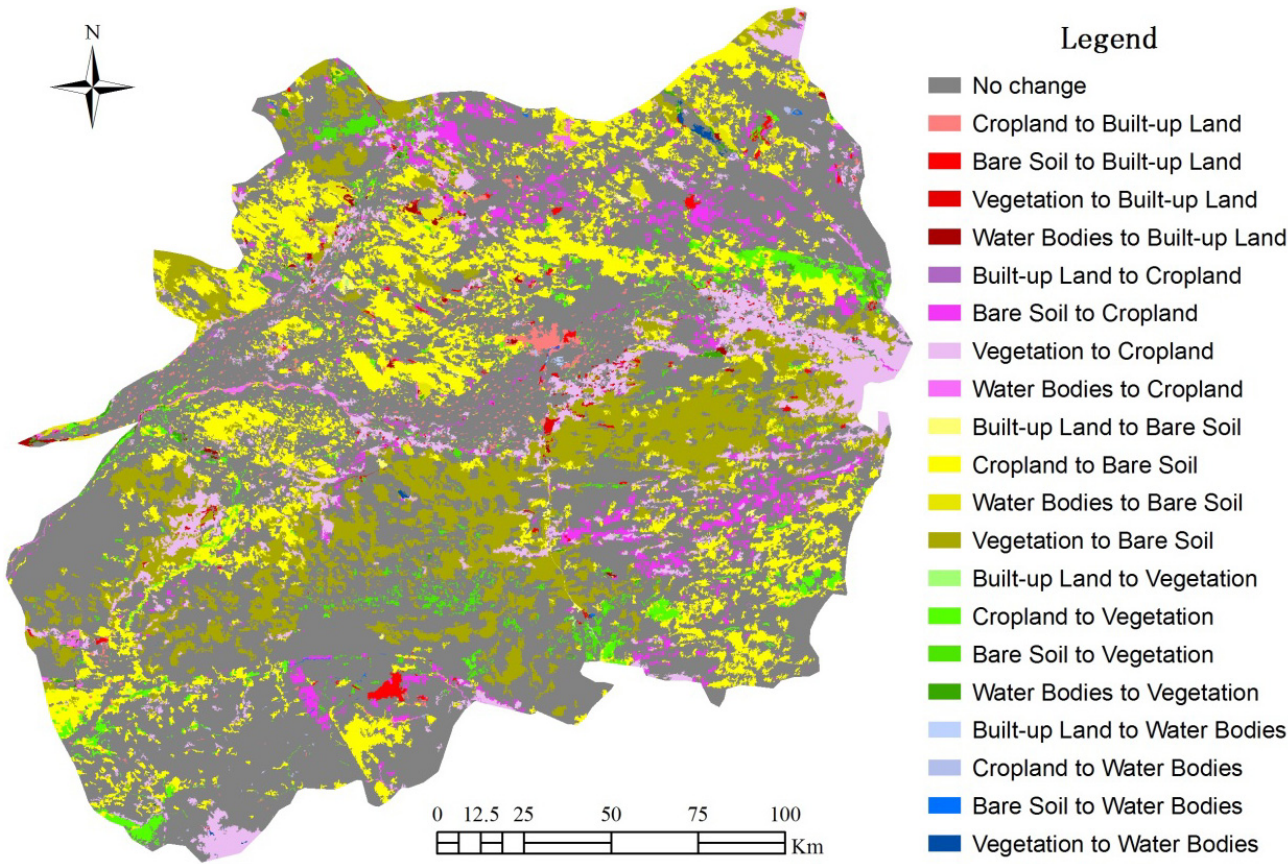

Figure 8. Change detection result map of the study area based on the post-classification comparison (PCC) method from 2003 to 2010.

Both sets of LU/LC classification map in 2010 (Figure 6b) and CD map (Figure 8) show that a vast expansion of built-up lands along the Xiliao River Basin has occurred over the seven-year period. This change is the result of government initiatives (as mentioned earlier) and population growth. Rapid contraction and exhaustion of water bodies occur in areas with increased built-up lands and irrigated croplands (Figures $6 \mathrm{~b}$ and 8). During the seven-year period, the new villages and the expanded urban areas, particularly Tongliao City, became nearly distributed along the Xiliao River Basin and lakes. Meanwhile, croplands became increasingly dependent on irrigation. Therefore, large areas of irrigated croplands expanded rapidly along water bodies because access to surface water or groundwater was available. Consequently, water consumption increased. In addition to human factors, this region has been under threat from declining rainfall since 1999, increasing temperatures, and frequent windy weather and sandstorms, which have increased water evaporation. Therefore, the area of water bodies decreased by a factor of more than five from $2.1 \%$ in 2003 to $0.4 \%$ in 2010 . Figure $6 \mathrm{~b}$ shows that the water of the Xiliao River Basin has nearly dried up.

The following findings can be determined from the analysis of the "from-to" land use change matrix in Table 3. (1) The no change area (gray area in Figure 8) is $23,414.8 \mathrm{~km}^{2}$, which accounts for $57.7 \%$ of the total area $\left(40,559.3 \mathrm{~km}^{2}\right)$; (2) Bare soil expansion encroaches on vegetation, croplands, and water bodies, with the largest encroachment occurring on croplands (5524.2 km²); (3) The commutative change extent between vegetation and bare soil is also highly extensive (5192.2 km²); (4) Cropland loss has a high negative correlation with other land use changes. If Horqin Sandy Land has a high cropland loss rate, then the expansion rate of built-up lands and the increase rate of bare soil are also high. This finding implies that large areas of croplands are transformed into built-up lands and bare soil; however, these lands do not transform into croplands accordingly; (5) In addition to the major conversion of vegetation areas and croplands into bare soil, other LU/LC changes are evident. These changes include the transitions of croplands into built-up lands $\left(281.1 \mathrm{~km}^{2}\right)$ and vegetation $\left(724.3 \mathrm{~km}^{2}\right)$, and the conversion of bare soil into croplands $\left(1210.3 \mathrm{~km}^{2}\right)$, as well as the reversals of these changes in some instances; (6) Over the aforementioned period, the total area of vegetation decreased from $21.5 \%$ to $5.5 \%$. However, a major conversion of the cropland and bare soil areas occurred, which were $724.3 \mathrm{~km}^{2}$ and $439.6 \mathrm{~km}^{2}$, respectively. This phenomenon could be attributed to the Sloping Land 
Conversion Program in 1999, which was also known as "Grain for Green". This national policy was introduced in different manners in Inner Mongolia, with a particular emphasis on Horqin Sandy Land.

Table 3. LU/LC change matrix in Horqin Sandy Land in 2003-2010 (km²).

\begin{tabular}{|c|c|c|c|c|c|c|c|c|}
\hline & & \multicolumn{5}{|c|}{2010} & \multirow[b]{2}{*}{ Total } & \multirow[b]{2}{*}{ Decrease } \\
\hline & & $\begin{array}{c}\text { Built-up } \\
\text { Lands }\end{array}$ & $\begin{array}{l}\text { Water } \\
\text { Bodies }\end{array}$ & $\begin{array}{l}\text { Bare } \\
\text { Soil }\end{array}$ & Croplands & Vegetation & & \\
\hline \multirow{5}{*}{2003} & Built-up lands & 191.4 & 5.8 & 99.2 & 94.9 & 20.4 & 411.7 & 220.3 \\
\hline & Water bodies & 69.3 & 82.3 & 404.5 & 195.8 & 114.5 & 866.4 & 784.1 \\
\hline & Bare soil & 136.9 & 12.1 & $10,557.5$ & 1210.3 & 439.6 & $12,356.4$ & 1798.9 \\
\hline & Croplands & 281.1 & 24.5 & 5524.2 & $11,657.0$ & 724.3 & $18,211.1$ & 6554.1 \\
\hline & Vegetation & 99.2 & 27.7 & 5192.2 & 2468.0 & 926.6 & 8713.7 & 7787.1 \\
\hline & Total & 777.9 & 152.4 & $21,777.6$ & $15,626.0$ & 2225.4 & $40,559.3$ & \multirow[t]{2}{*}{$17,144.5$} \\
\hline & Increase & 586.5 & 70.1 & $11,220.1$ & 3969 & 1298.8 & $17,144.5$ & \\
\hline
\end{tabular}

Over the past seven years, man has rapidly and extensively accelerated land use changes. One of the most significant effects of human activities on land use is water change [66]. Accelerated economic development has resulted in the considerable increase of the urbanization rate in Horqin Sandy Land, which significantly boosts the expansion of urban areas. Such expansion has simultaneously led to high water consumption. In the study area, poor farmers have also transformed vegetation areas into croplands to increase their income, which increases water consumption. In addition to human factors, climate changes, such as the increase in temperature and evaporation and the decrease in rainfall, further exacerbate the problem of water storage decrease. Considering the negative ecological effects of LU/LC changes, the national and local governments of China have implemented numerous policies to reduce their negative effects on the local environment. However, LU/LC changes and their corresponding mechanism in Horqin Sandy Land are complicated. The effect of the implemented policies is not evident. Therefore, strategies that can help detect and overcome these difficulties are still required. Such strategies can also improve understanding of the effects of LU/LC changes on water storage and climate systems.

\subsection{Effects of LU/LC Changes on GWS}

GWS is controlled by both natural processes, such as precipitation and evaporation, and human activities, such as industrial and domestic consumption and agricultural irrigation $[67,68]$. The effects of these factors on groundwater circulation can either be direct or indirect. As shown in Figure 3c,d, TWS and soil moisture changes highly depend on precipitation. However, except in 2009, annual precipitation is close to normal (approximately $350 \mathrm{~mm}$, as shown in Figure 3d), whereas GWS presents a continuously decreasing tendency (shown in Figures 4 and 5c). Rodell et al. [47] found a similar relationship between precipitation and GWS over the Indian states of Rajasthan, Punjab, and Haryana. The continuous decrease of GWS has been proven to be caused by the unsustainable consumption of groundwater for irrigation and other anthropogenic uses [47]. We propose that the most probable reason for groundwater level change in Horqin Sandy Land is human activities based on this finding. Humans have been reclaiming land to obtain food and other staples for thousands of years, which leads to tremendous changes in LU/LC. These changes involve forests, croplands, water bodies, and built-up lands. Such changes in LU/LC have enabled humankind not only to extract Earth resources continuously but also to decrease groundwater level gradually.

The distribution of LU/LC is apparently mainly determined by natural factors, such as water sources, terrain, and soil texture. Apart from their apparent effects, natural factors also influence anthropogenic activities, and thus, indirectly affect LU/LC. The Xiliao River Basin occupies the central part of Horqin Sandy Land and its alluvial sediments constitute the Xiliao River Plain, which has fertile soil to cultivate cropland and grow vegetation. Productivity is high on the plain but low on bare 
soil, which is mainly distributed in the southern part, with a small proportion in the northern part. However, the Xiliao River Basin is beginning to run dry. Apart from the social and natural factors mentioned in Section 4.2, another primary reason for this condition is that the Xiliao River Basin is located at the middle part of the Liao River, and its inflow is restricted by the upriver movement in Chifeng Prefecture. Considering the persistent drought and increasing water consumption in recent years, Chifeng has adopted the tactic of blocking off the upriver movement of the Liao River and establishing water conservation projects. Meanwhile, the Inner Mongolia Autonomous Region has not promulgated any official scheme of initial water right allocation in the Liao River Basin and has not formed the water coordination mechanism of upstream and downstream movements. These observations ultimately results in the annual average entry water being less than 50 million $\mathrm{m}^{3}$ and most of the rivers and reservoirs in Tongliao drying up. However, the annual average entry water in Chifeng is 510 million $\mathrm{m}^{3}$. In Horqin Sandy Land, groundwater is mainly recharged by rain and surface water, such as rivers and lakes. Surface water and groundwater are separate entities [69]. Once water demand exceeds the available surface supply, the correlation between the two entities will increase. The exhaustion of surface water sources for social consumption leads to groundwater depletion. However, if surface water sources are sufficient as a result of developing water resources and cooperating with frontier rivers, then groundwater sources may rise to normal levels and then retrain.

Tongliao City Prefecture, known as the "Granary of Inner Mongolia" and the "Golden Maize Zone", is a major grain-production base in China. Its total grain production accounts for over $25 \%$ of the production in Inner Mongolia. The main crops are maize, wheat, sorghum, millet, and beans, with patches of rice on river valleys [25]. Tongliao, which is located in a semiarid area, frequently suffers from drought (the frequencies of spring drought are up to $90 \%$ and those of summer-to-autumn continuous drought are between $50 \%$ and $60 \%$ ), which is a major factor that restricts agricultural and economic developments. Meanwhile, surface water has nearly dried up, and thus, the vast majority of croplands in the plain area use groundwater for agricultural irrigation. Ge [70] performed investigations among Naiman County farmers in 2004, 2008, and 2009, and found that $96.4 \%$ of the farmers believed that pumping groundwater for irrigation was necessary. Thus, groundwater irrigation provides a reliable guarantee for stable and high-yield grain production. However, the rate of effective water utilization is low. Agriculture in Horqin Sandy Land is characterized by a weak infrastructure as well as backward management and irrigation equipment because of financial restrictions.

In the north and south sides of the study area, the increase in the area of bare soil at the expanse of vegetation areas threatens the living conditions of farmers and shepherds. Local residents have moved from this fragile environment and settled in new villages and cities along the Xiliao River Basin to prevent sand land expansion and to improve living conditions, which leads to built-up land increase, urban expansion, and industrial development. Their water sources come from groundwater. However, the groundwater utilization structure is unreasonable. First, the water-saving technologies and infrastructure of the majority of the local industry enterprises are decades behind compared with those of developed countries. They are also characterized by high water consumption and emission as well as low output and added value, which limit the reutilization ratio of water to $50 \%$. Second, the water supply networks of cities and towns cannot easily satisfy the demand of modern urban development.

Consequently, Horqin Sandy Land has a large groundwater exploration base and a low water utilization rate, which are the primary reasons for groundwater overexploitation resulting from LU/LC changes. Overall plans for land and groundwater use should be introduced to address this problem and protect groundwater sources [71,72]. The government should formulate rational planning for groundwater and land resources. This area should reinforce the development of agricultural and industrial water-conservation projects to improve water efficiency, such as introducing advanced water-saving management, technologies, and equipment; strictly restricting the planting area of high water-consuming and low-output crops; and increasing the planting area of low water-consuming, high-output, and drought-resistant crops. Inter-basin water transfer planning should also be fully 
implemented to fill in the urban water demand-supply gap and to maintain normal groundwater levels. Through these measures, Horqin Sandy Land will progress in terms of both economic development and environmental protection.

\section{Conclusions}

The point-to-regional-scale analysis and the various approaches used in this study, including GWS estimation based on GRACE, GLDAS, and monitoring well data as well as LU/LC CD based on bitemporal Landsat TM imageries, complemented one another efficiently to develop a general understanding of the effect of LU/LC changes on GWS. The general result of this study indicates that the decline of groundwater level is related to LU/LC changes. The decline rate in Horqin Sandy Land between 2003 and 2010 is $-13.5 \pm 1.9 \mathrm{~mm} \cdot$ year $^{-1}$. Meanwhile, LU/LC significantly changed during the aforementioned period. In particular, the areas of bare soil and built-up lands increased dramatically, whereas those of croplands, vegetation, and water bodies decreased significantly. In the persistent drought-stricken and highly-productive agricultural areas of Horqin Sandy Land, most residents rely on groundwater as their primary source of domestic water and irrigation water. The strong correlation between groundwater and LU/LC found in this study suggests that management changes in LU/LC can be used to control GWS and increase groundwater levels.

Acknowledgments: This research is funded by the National Sciences Foundation of China (No. 41301586). The authors would like to thank the Center for Space Research at the University of Texas at Austin for providing the Release-05 Level-2 data, the China Geological Environmental Monitoring the Groundwater Level Yearbook for providing in situ monitoring well observations, and the Geospatial Data Cloud for providing Landsat TM imageries. We sincerely thank the editor and the three anonymous reviewers for their valuable and constructive comments. This manuscript has been improved as a result of their suggestions.

Author Contributions: Zhenzhen Zhao and Aiwen Lin contributed to the study design. Jiandi Feng, Qian Yang and Ling Zou contributed to the data collection and analyses. Zhenzhen Zhao conducted the data analyses and wrote the manuscript. All authors participated in reading and finalizing the manuscript.

Conflicts of Interest: The authors declare no conflict of interest.

\section{References}

1. Famiglietti, J.S.; Lo, M.; Ho, S.L.; Bethune, J.; Anderson, K.J.; Syed, T.H.; Swenson, S.C.; de Linage, C.R.; Rodell, M. Satellites measure recent rates of groundwater depletion in California's Central Valley. Geophys. Res. Lett. 2011, 38, L03403-L03406. [CrossRef]

2. Alley, W.M.; Healy, R.W.; LaBaugh, J.W.; Reilly, T.E. Hydrology-Flow and storage in groundwater systems. Science 2002, 296, 1985-1990. [CrossRef] [PubMed]

3. Wada, Y.; van Beek, L.P.H.; van Kempen, C.M.; Reckman, J.W.T.M.; Vasak, S.; Bierkens, M.F.P. Global depletion of groundwater resources. Geophys. Res. Lett. 2010, 37, 114-122. [CrossRef]

4. Gleeson, T.; Wada, Y.; Bierkens, M.F.P.; van Beek, L.P.H. Water balance of global aquifers revealed by groundwater footprint. Nature 2012, 488, 197-200. [CrossRef] [PubMed]

5. Siebert, S.; Burke, J.; Faures, J.M.; Frenken, K.; Hoogeveen, J.; Doll, P.; Portmann, F.T. Groundwater use for irrigation-A global inventory. Hydrol. Earth Syst. Sci. 2010, 14, 1863-1880. [CrossRef]

6. Scanlon, B.R.; Jolly, I.; Sophocleous, M.; Zhang, L. Global impacts of conversions from natural to agricultural ecosystems on water resources: Quantity versus quality. Water Resour. Res. 2007, 43, 455-456. [CrossRef]

7. Hanasaki, N.; Kanae, S.; Oki, T.; Masuda, K.; Motoya, K.; Shirakawa, N.; Shen, Y.; Tanaka, K. An integrated model for the assessment of global water resources-Part 2: Applications and assessments. Hydrol. Earth Syst. Sci. 2008, 12, 1027-1037. [CrossRef]

8. Hanasaki, N.; Kanae, S.; Oki, T.; Masuda, K.; Motoya, K.; Shirakawa, N.; Shen, Y.; Tanaka, K. An integrated model for the assessment of global water resources-Part 1: Model description and input meteorological forcing. Hydrol. Earth Syst. Sci. 2008, 12, 1007-1025. [CrossRef]

9. Feng, W.; Zhong, M.; Lemoine, J.-M.; Biancale, R.; Hsu, H.-T.; Xia, J. Evaluation of groundwater depletion in north China using the gravity recovery and climate experiment (grace) data and ground-based measurements. Water Resour. Res. 2013, 49, 2110-2118. [CrossRef] 
10. Scanlon, B.R.; Longuevergne, L.; Long, D. Ground referencing grace satellite estimates of groundwater storage changes in the California Central Valley, USA. Water Resour. Res. 2012, 48, 142-148. [CrossRef]

11. López-Vera, F. Groundwater: The invisible resource. Int. J. Water Resour. D 2012, 28, 141-150. [CrossRef]

12. Rodell, M.; Chen, J.L.; Kato, H.; Famiglietti, J.S.; Nigro, J.; Wilson, C.R. Estimating groundwater storage changes in the Mississippi River Basin (USA) using grace. Hydrogeol. J. 2007, 15, 159-166. [CrossRef]

13. Tapley, B.D.; Bettadpur, S.; Ries, J.C.; Thompson, P.F.; Watkins, M.M. Grace measurements of mass variability in the earth system. Science 2004, 305, 503-505. [CrossRef] [PubMed]

14. Yeh, P.J.F.; Swenson, S.C.; Famiglietti, J.S.; Rodell, M. Remote sensing of groundwater storage changes in illinois using the gravity recovery and climate experiment (grace). Water Resour. Res. 2006, 42, 395-397. [CrossRef]

15. Zaitchik, B.F.; Rodell, M.; Reichle, R.H. Assimilation of grace terrestrial water storage data into a land surface model: Results for the Mississippi River Basin. J. Hydrometeorol. 2008, 9, 535-548. [CrossRef]

16. Wada, Y.; Wisser, D.; Bierkens, M.F.P. Global modeling of withdrawal, allocation and consumptive use of surface water and groundwater resources. Earth Syst. Dynam. 2014, 5, 15-40. [CrossRef]

17. Pokhrel, Y.N.; Koirala, S.; Yeh, P.J.F.; Hanasaki, N.; Longuevergne, L.; Kanae, S.; Oki, T. Incorporation of groundwater pumping in a global land surface model with the representation of human impacts. Water Resour. Res. 2015, 51, 78-96. [CrossRef]

18. Bagan, H.; Takeuchi, W.; Kinoshita, T.; Bao, Y.H.; Yamagata, Y. Land cover classification and change analysis in the Horqin Sandy Land from 1975 to 2007. IEEE J. Sel. Top. Appl. Earth Obs. Remote Sens. 2010, 3, 168-177. [CrossRef]

19. Jiang, G.M.; Han, X.G.; Wu, J.G. Restoration and management of the inner mongolia grassland require a sustainable strategy. Ambio 2006, 35, 269-270. [CrossRef] [PubMed]

20. Katoh, K.; Takeuchi, K.I.; Jiang, D.M.; Nan, Y.H.; Kou, Z.W. Vegetation restoration by seasonal exclosure in the Kerqin Sandy Land, inner Mongolia. Plant Ecol. 1998, 139, 133-144. [CrossRef]

21. Sasaki, T.; Okubo, S.; Okayasu, T.; Jamsran, U.; Ohkuro, T.; Takeuchi, K. Two-phase functional redundancy in plant communities along a grazing gradient in Mongolian rangelands. Ecology 2009, 90, 2598-2608. [CrossRef] [PubMed]

22. Wu, J.; Vincent, B.; Yang, J.; Bouarfa, S.; Vidal, A. Remote sensing monitoring of changes in soil salinity: A case study in inner Mongolia, China. Sensors 2008, 8, 7035-7049. [CrossRef]

23. Kou, Z. Amelioration of desertification and construction of sustainable landuse system in Wulan-Aodu area. In Towards Solving the Global Desertification Problem; National Institute for Environmental Studies: Tsukuba, Japan, 1994; Volume 4, pp. 45-47.

24. Li, Y.; Cui, J.; Zhang, T.; Okuro, T.; Drake, S. Effectiveness of sand-fixing measures on desert land restoration in Kerqin Sandy Land, northern China. Ecol. Eng. 2009, 35, 118-127. [CrossRef]

25. Brogaard, S.; Li, X. Agricultural performance on marginal land in eastern inner Mongolia, China-Development in the pre- and post-1978 reform periods. GeoJournal 2005, 64, 163-175. [CrossRef]

26. Yan, Y.; Zhu, J.; Yan, Q.; Zheng, X.; Song, L. Modeling shallow groundwater levels in Horqin Sandy Land, north China, using satellite-based remote sensing images. J. Appl. Remote Sens. 2014, 8, 083647. [CrossRef]

27. Cao, C.; Jiang, D.; Teng, X.; Jiang, Y.; Liang, W.; Cui, Z. Soil chemical and microbiological properties along a chronosequence of Caragana microphylla Lam. Plantations in the Horqin Sandy Land of northeast China. Appl. Soil Ecol. 2008, 40, 78-85. [CrossRef]

28. Han, M.; Zhao, Y.; Zhang, D. Agricultural reclamations in Xiliao River Valley, China since the Holocene. J. Geogr. Sci. 2012, 22, 371-381. [CrossRef]

29. Chambers, D.P.; Bonin, J.A. Evaluation of release-05 grace time-variable gravity coefficients over the ocean. Ocean Sci. 2012, 8, 859-868. [CrossRef]

30. Swenson, S.; Yeh, P.J.F.; Wahr, J.; Famiglietti, J. A comparison of terrestrial water storage variations from grace with in situ measurements from Illinois. Geophys. Res. Lett. 2006. [CrossRef]

31. Paulson, A.; Zhong, S.J.; Wahr, J. Inference of mantle viscosity from grace and relative sea level data. Geophys. J. Int. 2007, 171, 497-508. [CrossRef]

32. Velicogna, I.; Wahr, J. Acceleration of greenland ice mass loss in spring 2004. Nature 2006, 443, 329-331. [CrossRef] [PubMed]

33. Longuevergne, L.; Scanlon, B.R.; Wilson, C.R. Grace hydrological estimates for small basins: Evaluating processing approaches on the high plains aquifer, USA. Water Resour. Res. 2010. [CrossRef] 
34. Longuevergne, L.; Wilson, C.R.; Scanlon, B.R.; Crétaux, J.F. Grace water storage estimates for the middle east and other regions with significant reservoir and lake storage. Hydrol. Earth Syst. Sci. 2013, 17, 4817-4830. [CrossRef]

35. Long, D.; Longuevergne, L.; Scanlon, B.R. Global analysis of approaches for deriving total water storage changes from grace satellites. Water Resour. Res. 2015, 51, 2574-2594. [CrossRef]

36. Long, D.; Yang, Y.; Wada, Y.; Hong, Y.; Liang, W.; Chen, Y.; Yong, B.; Hou, A.; Wei, J.; Chen, L. Deriving scaling factors using a global hydrological model to restore grace total water storage changes for China's Yangtze River Basin. Remote Sens. Environ. 2015, 168, 177-193. [CrossRef]

37. Landerer, F.W.; Swenson, S.C. Accuracy of scaled grace terrestrial water storage estimates. Water Resour. Res. 2012. [CrossRef]

38. Wahr, J.; Swenson, S.; Velicogna, I. Accuracy of grace mass estimates. Geophys. Res. Lett. 2006. [CrossRef]

39. Yu, C.J. Dynamic Simulation Evaluation about Water Resource System and Opimal Allocation Model of Macro-Economy Water Resource in Tong Liao City. Ph.D. Thesis, Inner Mongolia Agricultural University, Hohhot, China, 2004. (In Chinese)

40. Yang, Q.; Lun, W.; Fang, Y. Numerical modeling of three dimension groundwater flow in Tongliao (China). Procedia Eng. 2011, 24, 638-642. [CrossRef]

41. Duan, Q.M. Research on Three-Dimensional Geologic Modeling and Numerical Simulation of Groundwater in Xiliao River Plain. Ph.D. Thesis, China University of Geosciences, Beijing, China, 2006. (In Chinese)

42. Moiwo, J.P.; Lu, W.; Tao, F. Grace, gldas and measured groundwater data products show water storage loss in western Jilin, China. Water Sci. Technol. 2012, 65, 1606-1614. [CrossRef] [PubMed]

43. Wei, Y.F.; Fang, J.; Liu, S.; Zhao, X.Y.; Li, S.G. Stable isotopic observation of water use sources of Pinus sylvestris var. mongolica in Horqin Sandy Land, China. Trees 2013, 27, 1249-1260.

44. Rodell, M.; Houser, P.R.; Jambor, U.; Gottschalck, J.; Mitchell, K.; Meng, C.J.; Arsenault, K.; Cosgrove, B.; Radakovich, J.; Bosilovich, M.; et al. The global land data assimilation system. Bull. Am. Meteorol. Soc. 2004, 85, 381-394. [CrossRef]

45. Long, D.; Scanlon, B.R.; Longuevergne, L.; Sun, A.Y.; Fernando, D.N.; Save, H. Grace satellite monitoring of large depletion in water storage in response to the 2011 drought in Texas. Geophys. Res. Lett. 2013, 40, 3395-3401. [CrossRef]

46. Long, D.; Longuevergne, L.; Scanlon, B.R. Uncertainty in evapotranspiration from land surface modeling, remote sensing, and grace satellites. Water Resour. Res. 2014, 50, 1131-1151. [CrossRef]

47. Rodell, M.; Velicogna, I.; Famiglietti, J.S. Satellite-based estimates of groundwater depletion in India. Nature 2009, 460, 999-1002. [CrossRef] [PubMed]

48. Schroeder, T.A.; Cohen, W.B.; Song, C.; Canty, M.J.; Yang, Z. Radiometric correction of multi-temporal landsat data for characterization of early successional forest patterns in western Oregon. Remote Sens. Environ. 2006, 103, 16-26. [CrossRef]

49. Song, C.L.; Woodcock, C.E.; Seto, K.C.; Lenney, M.P.; Macomber, S.A. Classification and change detection using landsat TM data: When and how to correct atmospheric effects? Remote Sens. Environ. 2001, 75, 230-244. [CrossRef]

50. Yalçıntaş, M.; Bulu, M.; Küçükvar, M.; Samadi, H. A framework for sustainable urban water management through demand and supply forecasting: The case of Istanbul. Sustainability 2015, 7, 11050-11067. [CrossRef]

51. Im, J.; Rhee, J.; Jensen, J.R.; Hodgson, M.E. An automated binary change detection model using a calibration approach. Remote Sens. Environ. 2007, 106, 89-105. [CrossRef]

52. Mas, J.F. Monitoring land-cover changes: A comparison of change detection techniques. Int. J. Remote Sens. 1999, 20, 139-152. [CrossRef]

53. Araya, Y.H.; Hergarten, C. A comparison of pixel and object-based land cover classification: A case study of the Asmara region, Eritrea. WIT Trans. Built Environ. 2008, 100, 233-243.

54. Chen, X.H.; Chen, J.; Shi, Y.S.; Yamaguchi, Y. An automated approach for updating land cover maps based on integrated change detection and classification methods. ISPRS J. Photogramm. Remote Sens. 2012, 71, 86-95. [CrossRef]

55. Lu, D.; Mausel, P.; Brondizio, E.; Moran, E. Change detection techniques. Int. J. Remote Sens. 2004, 25, 2365-2407. [CrossRef]

56. Blaschke, T. Object based image analysis for remote sensing. ISPRS J. Photogramm. Remote Sens. 2010, 65, 2-16. [CrossRef] 
57. Hay, G.J.; Blaschke, T. Special issue: Geographic object-based image analysis (GEOBIA) foreword. Photogramm. Eng. Remote Sens. 2010, 76, 121-122.

58. Li, J.; Liu, Y.; Cao, M.; Xue, B. Space-time characteristics of vegetation cover and distribution: Case of the Henan Province in China. Sustainability 2015, 7, 11967-11979. [CrossRef]

59. Rudorff, B.F.T.; Adami, M.; Risso, J.; de Aguiar, D.A.; Pires, B.; Amaral, D.; Fabiani, L.; Cecarelli, I. Remote sensing images to detect soy plantations in the Amazon biome-The soy moratorium initiative. Sustainability 2012, 4, 1074-1088. [CrossRef]

60. Sizo, A.; Noble, B.; Bell, S. Futures analysis of urban land use and wetland change in Saskatoon, Canada: An application in strategic environmental assessment. Sustainability 2015, 7, 811-830. [CrossRef]

61. Cao, Y.; Nan, Z.; Cheng, G. Grace gravity satellite observations of terrestrial water storage changes for drought characterization in the arid land of northwestern China. Remote Sens. 2015, 7, 1021-1047. [CrossRef]

62. Gao, H.; Yang, S. A severe drought event in northern China in winter 2008-2009 and the possible influences of La Niña and Tibetan Plateau. J. Geophys. Res. 2009. [CrossRef]

63. Ye, Q. Research on Resource Efficiency of Agricultural Production in Horqin Sandy Land. Master's Thesis, Huazhong Agricultural University, Wuhan, China, 2011. (In Chinese)

64. Song, Q.Y. The Study on the Water Saving Potential of Agricultural in Keerqin District of Tongliao City. Master's Thesis, Chinese Academy of Agricultural Sciences, Beijing, China, 2007. (In Chinese)

65. Guo, B.; Li, W.; Guo, J.; Chen, C. Risk assessment of regional irrigation water demand and supply in an arid inland river basin of northwestern China. Sustainability 2015, 7, 12958-12973. [CrossRef]

66. Motoshita, M.; Ono, Y.; Finkbeiner, M.; Inaba, A. The effect of land use on availability of Japanese freshwater resources and its significance for water footprinting. Sustainability 2016. [CrossRef]

67. Dams, J.; Woldeamlak, S.T.; Batelaan, O. Predicting land-use change and its impact on the groundwater system of the Kleine Nete catchment, Belgium. Hydrol. Earth Syst. Sci. 2008, 12, 1369-1385. [CrossRef]

68. Scanlon, B.R.; Reedy, R.C.; Stonestrom, D.A.; Prudic, D.E.; Dennehy, K.F. Impact of land use and land cover change on groundwater recharge and quality in the southwestern US. Glob. Chang. Biol. 2005, 11, 1577-1593. [CrossRef]

69. Hoekstra, A.; Chapagain, A.; Zhang, G. Water footprints and sustainable water allocation. Sustainability 2015. [CrossRef]

70. Ge, X.D.; Huang, C.; Ye, Q. Agricultural production technical efficiency in horiqn sandy land during 2000-2008: A case study in Tongliao. J. Desert Res. 2012, 32, 1457-1462.

71. Ma, D.; Xian, C.; Zhang, J.; Zhang, R.; Ouyang, Z. The evaluation of water footprints and sustainable water utilization in Beijing. Sustainability 2015, 7, 13206-13221. [CrossRef]

72. Yu, X.; Geng, Y.; Heck, P.; Xue, B. A review of China's rural water management. Sustainability 2015, 7, 5773-5792. [CrossRef]

(C) 2016 by the authors; licensee MDPI, Basel, Switzerland. This article is an open access article distributed under the terms and conditions of the Creative Commons by Attribution (CC-BY) license (http:/ / creativecommons.org/licenses/by/4.0/). 